Care: Jurnal Ilmiah Ilmu Kesehatan Vol .8, No.2, 2020, hal 176-184

Tersedia online di https://jurnal.unitri.ac.id/index.php/care

ISSN 2527-8487 (online)

ISSN 2089-4503 (cetak)

\title{
IDENTIFIKASI SENYAWA GARLISIN DAN KUERSETIN SEBAGAI SENYAWA ANTIMIKROBA PADA SEDIAAN BASAH DAN KERING \\ BAWANG PUTIH (Allium sativum L.)
}

\author{
Fanny Thresia Yunus ${ }^{1)}$, Ari Suwondo ${ }^{2)}$, Martini $^{3)}$ \\ 1),2),3) Program Studi Pascasarjana Epidemiologi Universitas Diponegoro \\ E-mail: fannythris@gmail.com
}

\begin{abstract}
Indonesian people have long used garlic as traditional medicine because it contains various chemical compounds that are beneficial to the body. In this study identification of garlicin and kuersetin compounds in garlic as an antibacterial. This study requires 500 grams of garlic each in wet preparations consist of fine garlic and garlic extract, and dry preparation consists of garlic powder. In addition, this research requires 2,1 liters of 96\% ethanol. Garlic is dried at $40^{\circ} \mathrm{C}$ with TMI Vacuum Oven and extracted at $25^{\circ} \mathrm{C}$. Garlic powder is made using Krisbow dry cabinet with a temperature of $100^{\circ} \mathrm{F}$ and a pressure of $10 \mathrm{~Pa}$. Garlisin content was identified by GCMS Shimadzu TQ8030 and FTIR Perkin Elmer Spectrum Two UATR, while identification of quercetin using Shimadzu HPLC type UFLC. The result shows that the compound garlicin $\left(\mathrm{C}_{6} \mathrm{H}_{10} \mathrm{~S}_{2}\right)$ was found in the three samples with identical similarity levels. In addition, the three samples showed differences in kuersetin content. The highest kuersetin content was 458.729 ppm garlic extract while the lowest kuersetin content was 81.181 ppm fresh garlic. Both of these compounds have potential as antimicrobial compounds.
\end{abstract}

Keywords : Garlic; garlicin; quercetin; antibacteria.

\begin{abstract}
ABSTRAK
Masyarakat indonesia sudah lama memanfaatkan bawang putih sebagai obat tradisional karena bawang putih mengandung berbagai senyawa kimia yang bermanfaat bagi tubuh. Tujuan penelitian ini yaitu untuk membuktikan adanya senyawa bioaktif garlisin dan kuersetin yang memiliki sifat antibakteri pada bawang putih. Penelitian ini membutuhkan masing-masing 500 gram bawang putih dalam bentuk sediaan basah berupa bawang putih halus dan ekstrak bawang putih, serta sediaan basah berupa serbuk bawang putih. Selain itu, penelitian ini membutuhkan 2,1 liter etanol 96\%. Bawang putih dikeringkan pada suhu $40^{\circ} \mathrm{C}$ dengan TMI Vacuum Oven dan dilakukan ekstraksi pada suhu $25^{\circ} \mathrm{C}$. Serbuk bawang
\end{abstract}

Cara mengutip: Yunus, F. Thresia., Suwondo, Ari., \& Martini. (2020). Identifikasi Senyawa Garlisin Dan Kuersetin Sebagai Senyawa Antimikroba Pada Sediaan Basah Dan Kering Bawang Putih (Allium sativum L.). Care:Jurnal Ilmiah Ilmu Kesehatan, 8(2), 176-184

Retrieved from https://jurnal.unitri.ac.id/index.php/care/article/view/1693 
putih dibuat dengan menggunakan $d r y$ cabinet Krisbow dengan suhu $100^{\circ} \mathrm{F}$ dan tekanan 10 Pa. Kandungan garlisin diidentifikasi dengan GCMS Shimadzu TQ8030 dan FTIR Perkin Elmer Spectrum Two UATR, sedangkan identifikasi kuersetin menggunakan HPLC Shimadzu tipe UFLC. Hasil penelitian membuktikan benar adanya senyawa garlisin atau diallyl disulfide $\left(\mathrm{C}_{6} \mathrm{H}_{10} \mathrm{~S}_{2}\right)$ yang ditemukan pada tiga sediaan. Kandungan kuersetin tertinggi terdapat pada ekstrak bawang putih sebanyak 458,729 ppm sedangkan kandungan kuersetin terendah terdapat pada bawang putih segar sebanyak 81,181 ppm.

Kata Kunci : Bawang Putih; garlisin; kuersetin; antibakteri.

\section{PENDAHULUAN}

Penyakit yang ditimbulkan akibat infeksi merupakan penyakit yang sering terjadi di di dunia. Kematian akibat penyakit infeksi lebih sering terjadi di negara berkembang akibat sanitasi dan higenitas lingkungan yang buruk (WHO, 2019). Menurut Merriman (2014) infeksi paling sering disebabkan oleh bakteria, virus, dan jamur.

Bakteri dapat dengan mudah menginfeksi tubuh melalui beberapa mekanisme. Menurut Hanson (2017) bakteri patogenik bersifat menular, dapat melekat pada host, dan menghasilkan racun. Hal tersebut diperjelas oleh Berne et al. (2015)bahwa bakteri patogen memiliki kapsul, toksin dan adhesin yang bereaksi dengan sel inang. Komponen tersebut yang menentukan patogenitas pada suatu kelompok bakteri. Penanganan infeksi yang disebabkan oleh bakteri biasanya menggunakan antibiotik untuk menghambat infeksi. Namun, penanganan infeksi bakteri dengan penggunaan antibiotik terkadang menimbulkan permasalahan baru yaitu resistensi bakteri.

Dampak resistensi bakteri terhadap antibiotik juga dapat meningkatkan angka kematian. Menurut CDC (2019) memperkirakan kasus kematian yang terjadi akibat resistensi antibiotik sebanyak 35.900 kasus kematian per tahun. Resistensi antibiotik dapat menyebabkan pengobatan semakin lama dan penyakit semakin susah diobati (Friedman et al., 2016). Resistensi terjadi apabila penggunaan antibiotik atau antimikroba semakin luas dan dengan jumlah yang berlebihan. Kasus resistensi antibiotik juga sering terjadi pada bakteri Stapylococcus aureus. Hal tersebut membuat menimbulkan masalah karena bakteri tersebut ternyata resisten terhadap berbagai jenis antibiotik. Kasus Metbicillin Resistant Staphyloccus aureus (MRSA) di Indonesia memiliki prevalensi yang tinggi 
di Indonesia. Hasil prevalensi MRSA terus meningkat dari tahun 2015 hingga tahun 2018 yaitu 7,69\%, 5,63\%, 10,85\%, dan 12,94\% (Nuryah et al., 2019).

Solusi untuk mengatasi kasus resistensi antibiotik oleh bakteri Stapylococcus aureus salah satunya dengan penggunaan bawang putih. Bawang putih (Allium sativum) termasuk tanaman yang tergolong famili Lilliaceae yang memiliki sifat antibakteri. Menurut Wolde et al. (2018) bawang putih dapat sigunakan sebagai antibakteri secara efektif untuk melawan bakteri patogen seperti E.coli dan S. aureus. Hal tersebut karena bawang putih mengandung senyawa organosulfur seperti diallyl disulfide yang bersifat sebagai antimikrobia dan antijamur (Shang et al., 2019).

Garlisin atau diallyl disulfide merupakan produk dari aktivitas enzim. Enzim yang berperan dalam proses sintesis garlisin adalah allinase ketika bawang dihancurkan (Nott \& Fauconnier, 2013). Selain itu, hasil penelitian Lekshmi \& Shobi (2015) menunjukkan bahwa senyawa kuersetin pada bawang putih dapat membentuk adanya zona hambat lebih dari $22 \mathrm{~mm}$ terhadap bakteri $S$. aureus. Oleh karena itu, senyawa tersebut sangat efekif sebagai antimikroba.
Senyawa garlisin dan kuersetin tersebut dapat diperoleh melalui berbagai metode ekstraksi dengan berbagai pelarut. Menurut Nikolovski \& Stupar, (2018) penggunaan pelarut etanol melarutkan garlisin lebih banyak dibandingkan dengan pelarut air. Selain itu, pelarut polar juga dapat melarutkan kuersetin lebih banyak karena senyawa tersebut termasuk flavonoid (Lekshmi \& Shobi, 2015). Selain itu, jenis sediaan juga berpengaruh terhadap senyawa yang dihasilkan.

Menurut

Samakradhamrongthai \& Utama-ang (2018) pengaruh suhu dan penghalusan bawang putih meningkatkan senyawa volatil dan alisin dari bawang putih kering. Oleh sebab itu, peneliti melakukan identifikasi senyawa garlisin dan kuersetin dengan menggunakan sediaan basah dan kering untuk mengetahui perbedaan garlisin dan kuersetin yang dihasilkan.

\section{METODE PENELITIAN}

Penelitian ini merupakan penelitian eksperimental laboratorium. Hal tersebut karena menggunakan sediaan dengan perlakuan yang terukur, terkendali, dan dapat dipercaya (Priyono, 2016). Penelitian ini digunakan bahan masingmasing 500 gram bawang putih untuk 
perlakuan bawang putih segar atau digerus, ekstrak bawang putih, dan bawang putih serbuk. Sediaan pertama digerus dalam kondisi segar. Sediaan kedua, bawang putih dilakukan pengeringan dengan TMI Vacuum Oven bersuhu $40^{\circ} \mathrm{C}$ untuk selanjutnya dihaluskan dan direndam pada 2 liter etanol 96\% selama $3 \times 24$ jam pada suhu ruang $25^{\circ} \mathrm{C}$. Rendaman tersebut kemudian disaring dan dipekatkan dengan menggunakan Rotary Evaporatory IKA HB 10 Basic pada suhu $40^{\circ} \mathrm{C}$ dan tekanan 175 bar.

Sediaan ketiga, bawang putih dikeringan pada dry cabinet Krisbow dengan suhu 100 F dan tekanan $10 \mathrm{~Pa}$ lalu dihaluskan dan diayak sampai berbentuk serbuk. Ketiga sediaan tersebut masing-masing diambil $10 \mathrm{mg}$ dan dilarutkan pada etanol 96\% untuk identifikasi garlisin menggunakan GCMS Shimadzu TQ8030. Pengambilan sediaan otomatis dilakukan oleh alat tersebut dengan ukuran 1 mikroliter. Selain itu, sebanyak $10 \mathrm{mg}$ untuk masingmasing sediaan juga diuji dengan FTIR Perkin Elmer Spectrum Two UATR untuk membuktikan adanya senyawa garlisin. Masing-masing sediaan diambil $10 \mathrm{mg}$ kemudian dilarutkan pada $10 \mathrm{ml}$. etanol 96\% untuk dianalisis menggunakan HPLC Shimadzu tipe UFLC untuk mengetahui kadar senyawa kuersetin pada masing-masing sediaan. Pengambilan sediaan otomatis dilakukan oleh alat tersebut dengan ukuran 1 mikroliter Pengujian tersebut dilakukan di Laboratorium Terpadu Universitas Diponegoro, Semarang, Jawa Tengah.

\section{HASIL}

\section{Identifikasi dengan GC-MS}

Fragmentasi GC-MS pada Gambar 1. menunjukan adanya senyawa garlisin pada bawang putih segar dengan tingkat kemiripan 79\% dengan senyawa garlisin pada library GC-MS, ekstrak bawang putih dengan tingkat kemiripan $75 \%$, dan serbuk bawang putih dengan tingkat kemiripan $81 \%$. Berdasarkan hasil analisis GC-MS untuk ketiga sediaan, tingkat kemiripan senyawa garlisin terbaik pada sediaan bawang putih serbuk, sedangkan tingkat kemiripan terendah dengan garlisin pada library GC-MS terdapat pada sediaan bawang putih yang diekstraksi dengan etanol $96 \%$. 

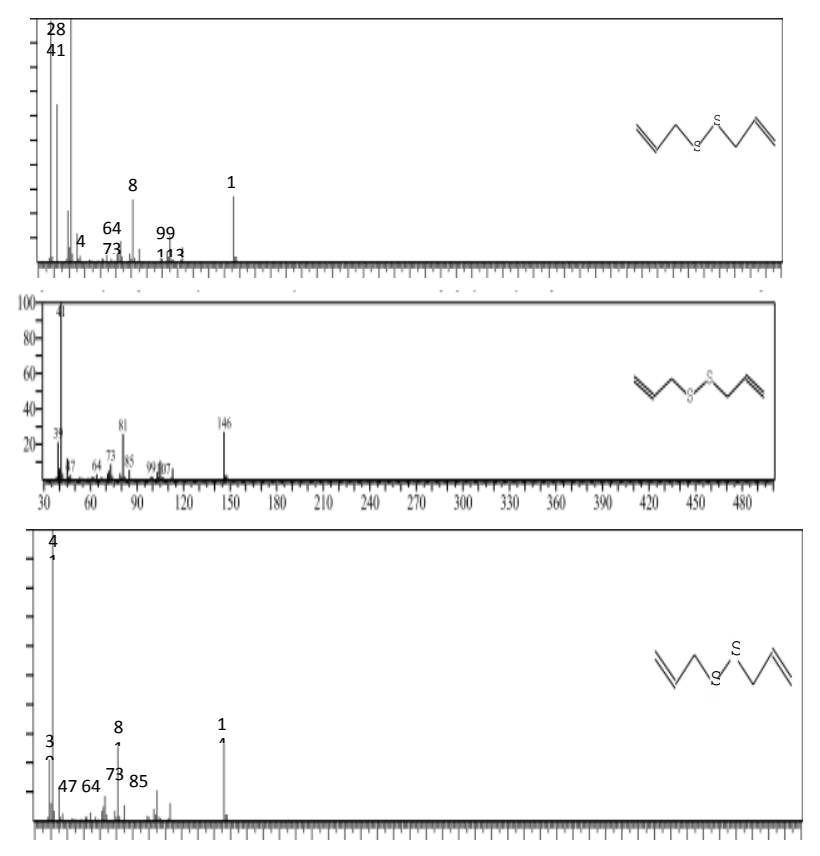

Gambar 1. Fragmentasi GC-MS Bawang Putih Segar (atas), ekstrak bawang putih (tengah), dan bawang putih serbuk (bawah)

\section{Hasil FTIR Bawang Putih}

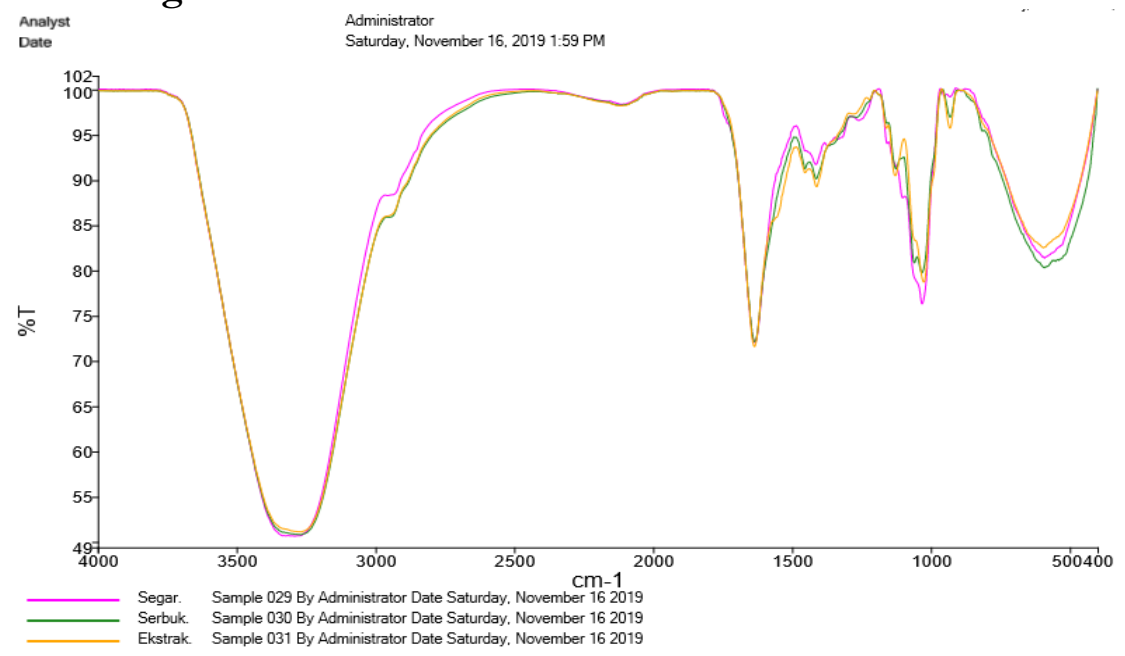

Gambar 2. Hasil Analisis FTIR Ketiga Sediaan Bawang Putih.

Dari hasil FTIR menunjukan spektra yang hampir sama dari ketiga sediaan.

Hasil Pengukuran Konsentrasi dengan HPLC. Senyawa kuersetin Kuersetin pada Bawang Putih dengan Metode HPLC

Gambar 3. Hasil pengukuran konsentrasi terdapat pada ketiga sediaan bawang putih dengan kadar yang berbeda.

kuersetin ketiga sediaan bawang putih 
Hasil dari kuersetin pada bawang putih segar sebesar 81,2 ppm, ekstrak bawang putih sebesar 458,73 ppm dan serbuk bawang putih sebesar 169,41 ppm.
Senyawa kuersetin dengan jumlah paling banyak terdapat pada sediaan ekstrak bawang putih.

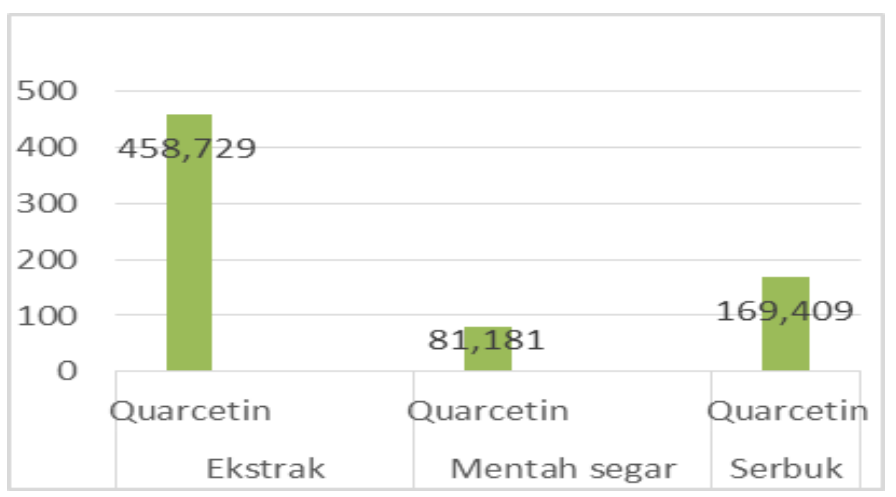

Gambar 3. Hasil Pengukuran Konsentrasi Kuersetin Ketiga Sediaan Bawang Putih

\section{PEMBAHASAN}

Pada pemeriksaan identifikasi senyawa Garlisin atau diallyl disulfide bawang putih segar menggunakan GC-MS ditemukan senyawa tersebut dengan tingkat kemiripan (SI) $79 \quad \%$ dengan library alat. Hal yang sama juga terdapat pada sediaan bawang putih serbuk yang memiliki senyawa garlisin yang memiliki tingkat kemiripan dengan library GC-MS sebesar 81\%. Kedua sediaan memiliki tingkat kemiripan diatas $75 \%$ yang mengindikasikan keberadaan dari senyawa Garlisin pada kedua sediaan bawang putih. Sediaan ekstrak dan sediaan tepung akan menghasilkan konsentrasi senyawa yang lebih tinggi dikarenakan berkurangnya kadar airnya dan meningkatnya kosentrasi senyawa bioaktif. Hal ini sejalan dengan hasil tingkat kemiripan senyawa garlisin pada sediaan bawang putih serbuk lebih tinggi dibanding sediaan bawang putih segar.

Garlisin merupakan komponen organosulfur yang terdapat pada bawang putih. Garlisin tersebut merupakan derivat alisin yang dapat diproduksi apabila sel bawang putih dirusak dengan cara ditumbuk atau dihaluskan (Prati et al., 2014). Oleh karena itu, serbuk bawang putih memiliki senyawa garlisin dengan tingkat kemiripan tertinggi dengan library GC-MS.

Enzim Alinase akan mengubah allin menjadi allisin yang bersifat kurang stabil terhadap suhu. Menurut Kemper (2015) 
apabila alisin dibiarkan pada suhu ruangan beberapa jam maka akan terbentuk senyawa turunannya seperti garlisin dan vynilthidiines. Oleh sebab itu, hasil analisis GC-MS dan FT-IR untuk ketiga sediaan tidak jauh berbeda akibat masing-masing sediaan bawang putih mengalami proses penghancuran sehingga diperoleh senyawa garlisin yang ditandai dengan adanya gugus fungsi organik sulfur pada bilangan gelombang $1026 \mathrm{~cm}^{-}$ ${ }^{1}$ yang didukung dengan adanya bilangan gelombang $595 \mathrm{~cm}^{-1}$ yang merupakan gugus fungsi sulfida. (Shriner, 2004).

Senyawa garlisin berpotensi sebagai senyawa antibakteri. Hal tersebut disebabkan karena senyawa tersebut dapat menghambat proses sinteis RNA dan DNA secara parsial serta memblok kerja enzim dengan gugus thiol pada bakteri (Müller et al., 2016). Hasil penelitian juga membuktikan bahwa kadar kuersetin paling banyak terdapat pada ekstrak bawang putih yang dimaserasi menggunakan etanol 96\%. Hal tersebut dikarenakan senyawa kuersetin termasuk jenis senyawa flavonoid yang larut pada pelarut polar, sehingga kuersetin dapat diperoleh dalam jumlah banyak dengan menggunakan pelarut yang sesuai. Hal tersebut sesuai dengan hasil penelitian Troter (2018) yang membuktikan bahwa etanol sangat efektif dalam proses ektraksi senyawa kuersetin dari bawang. Oleh karena itu, senyawa kuersetin dengan konsentrasi tertinggi terdapat pada ekstrak bawang putih.

Senyawa kuersetin bersifat antimikroba. Kuersetin memiliki sifat antibakteri terhadap $S$. aureus setelah masa inkubasi untuk menghasilkan zona hambat (Lekshmi \& Shobi, 2015). Selain itu, kuersetin memiliki gugus fenol yang dapat mengkoagulasi protein, mengganggu dinding sel dan bersifat bakterisidal yang baik (Azzahra et al., 2019). Apabila dinding sel bakteri tidak terbentuk, maka akan berakibat pada kebocoran sel dan kematian bakteri.

\section{KESIMPULAN}

Hasil penelitian menunjukan bahwa benar adanya senyawa garlisin pada umbi bawang putih segar dan serbuk bawang putih yang dibuktikan menggunakan GCMS dan FTIR. Senyawa garlisin atau diallyl disulfide $\left(\mathrm{C}_{6} \mathrm{H}_{10} \mathrm{~S}_{2}\right)$ yang ditemukan pada tiga sediaan tersebut dengan tingkat kemiripan yang identik. Selain itu, ketiga sediaan tersebut menunjukkan adanya perbedaan kandungan kuersetin. Kedua senyawa tersebut memiliki potensi sebagai senyawa antimikroba. 


\section{UCAPAN TERIMAKASIH}

Puji syukur kehadirat Tuhan yang Maha Esa, sehingga peneliti dapat menyelesaikan penelitian tepat waktu. Terima kasih peneliti ucapkan kepada Program Studi Magister Epidemiologi Universitas Diponegoro. Selain itu, peneliti mengucapkan terima kasih Dr. dr. Ari Suwondo, MPH selaku dosen pembimbing utama, Dr. Ir. Martini, M.Kes. selaku dosen pembimbing pendamping, Prof. Dr. dr. Suharyo Hadisaputro, Sp.PD (KPTI) selaku dosen penguji, seluruh staf pengajar Program Studi Magister Epidemiologi Universitas Diponegoro atas ilmu dan bimbingan yang sangat bermanfaat bagi peneliti. Terima kasih tidak lupa peneliti ucapkan kepada kedua orang tua tercinta dan rekan-rekan Program Studi Magister Epidemiologi UNDIP yang telah memberikan motivasi dalam menyelesaikan penelitian ini.

\section{REFERENSI}

Azzahra, F., Almalik, E. A., \& Sari, A. A. (2019). Uji Aktivitas Antibakteri dari Ekstrak Etanol Daun Alpukat (Persea Americanamil L.) terhadap Bakteri Salmonella typhi dan Staphylococcus aureus. Afkarindo, 4(2): 1-10.

Berne, C., Ducret, A., Hardy, G. G., \& Brun, Y. V. (2015). Adhesins Involved in Attachment to Abiotic Surfaces by Gram-Negative Bacteria. Microbiology Spectrum, 3(4):
$1-27$.

CDC. (2019). Antibiotic Resistance Threats in the United States, 2019. Atlanta: CDC Press

Friedman, N. D., Temkin, E., \& Carmeli, Y. (2016). The Negative Impact of Antibiotic Resistance. Clinical Microbiology and Infection, 22(5): 416422.

Hanson, L. A. (2017). Bacterial Pathogenesis Host-Parasite Relationships: Pathogenesis of Infections. Manglore.

Kemper, K. J. (2015). Garlic (Allium sativum L.). The Longwood Herbal Task Force and The Center for Holistic Pediatric Education and Research.

Lekshmi, P., \& Shobi, M. (2015). HPTLC Profile of Quercetin in Three Cultivars of Allium sativum and its Antimicrobial Activity against Bacterial Cultures. Journal of Chemical and Pharmaceutical Research, 7(3): 3843.

Merriman, H. (2014). Chapter 13 - Infectious Diseases. Acute Care Handbook for Physical Therapists (Fourth Edi). Amsterdam: Elsevier Inc.

Müller, A., Eller, J., Albrecht, F., Prochnow, P., Kuhlmann, K., Bandow, J. E., Leichert, L. I. O. (2016). Allicin Induces Thiol Stress in Bacteria through S-allylmercapto Modification of Protein Cysteines. Journal of Biological Chemistry, 291(22): 11477-11490.

Nikolovski, B., \& Stupar, A. (2018). Extraction of Different Garlic Varieties (Allium sativum L.) Determination of Organosulfur Compounds and Microbiological Activity. In International Congress "Food Technology, Quality and Safety (pp. 105-109).

Nott, K., \& Fauconnier, M. (2013). ( Bio )Synthesis, Extraction and Purification of Garlic Derivatives Showing Therapeutic Properties. Comm. Appl. Biol. Sci, 20(10): 1-8. 
Nuryah, A., Yuniarti, N., \& Puspitasari, I. (2019). Prevalensi dan Evaluasi Kesesuaian Penggunaan Antibiotik pada Pasien dengan Infeksi Methicillin Resistant Staphylococcus Aureus di RSUP Dr . Soeradji Tirtonegoro Klaten Prevalence and Evaluation of Suitability of Antibiotic use in Patients with Methicilli. Majalah Farmaseutik, 15(2): 123-129.

Prati, P., Henrique, C. M., Souza, A. S. De, Sônia, V., Teresa, M., \& Pacheco, B. (2014). Evaluation of Allicin Stability in Processed Garlic of Different Cultivars. Food Science and Technology, 34(3): 623-628.

Priyono. (2016). Metode Penelitian Kuantitatif (Zifatama). Sidoarjo: Zifatama.

Samakradhamrongthai, R. S., \& Utamaang, N. (2018). Effect of Drying Condition of Thai Garlic ( Allium sativum L .) on Physicochemical and Sensory Properties. International Food Research Journal 25(4): 1365-1372.

Shang, A., Cao, S., Xu, X., Gan, R., Tang, G., \& Corke, H. (2019). Bioactive
Compounds and Biological Functions of Garlic (Allium sativum L .) Bioactive Compounds and Biological Functions of Garlic ( Allium sativum L .). Foods, 8(246): $1-30$.

Shriner, Hermann, Morrill, Curtin, \& Fuson., (2004), The systematic Identification of Organic Compounds. (E. Edition, Ed.) (Vol. 108), John Wiley \& Sons, Inc

Troter, D. Z. (2018). The Extraction of Quercetin From Waste Onion (Allium Cepa L.) Tunic by the Aqueous Solutions of Different Deep Eutectic Solvents. Advanced Technology, 7(2): 5-10.

WHO. (2019). World Health Statistics Overview 2019: Monitoring Health for the SDGs, Sustainable Development Goals. Geneva: WHO Press.

Wolde, T., Kuma, H., Trueha, K., \& Yabeker, A. (2018). Anti-Bacterial Activity of Garlic Extract against Human Pathogenic Bacteria. J Pharmacovigil, 6(1): 1-5. 